Article

\title{
Molecular Viral Diagnosis and Sanitation of Yam Genetic Resources: Implications for Safe Yam Germplasm Exchange
}

\author{
Marie Umber ${ }^{1, * \mathbb{D}}$, Denis Filloux ${ }^{2,3}$, Suzia Gélabale ${ }^{1}$, Rose-Marie Gomez ${ }^{1}$, Armelle Marais ${ }^{4}$, \\ Séverine Gallet ${ }^{1}$, Franciane Gamiette ${ }^{1}$, Claudie Pavis ${ }^{1}$ and Pierre-Yves Teycheney ${ }^{5,6}{ }_{\mathbb{D}}$
}

1 Institut National de Recherche pour l'Agriculture, l'Alimentation et l'Environnement, Unité de Recherche Agrosystèmes Tropicaux, F-97170 Petit-Bourg, France; suzia.gelabale@inrae.fr (S.G.); rose-marie.gomez@inrae.fr (R.-M.G.); severine.gallet1@gmail.com (S.G.); franciane.gamiette@gageko.com (F.G.); claudie.pavis@gmail.com (C.P.)

2 Centre de Coopération Internationale en Recherche Agronomique Pour le Développement, Unité Mixte de Recherche-Biologie et Génétique des Interactions Plante-Parasite, F-34398 Montpellier, France; denis.filloux@cirad.fr

3 Biologie et Génétique des Interactions Plante-Parasite, Univ. Montpellier, Centre de Coopération Internationale en Recherche Agronomique Pour le Développement, Institut National de Recherche pour l'Agriculture, Montpellier SupAgro, F-34060 Montpellier, France

4 Institut National de Recherche pour l'Agriculture, l'Alimentation et l'Environnement, Université de Bordeaux, Unité Mixte de Recherche Biologie du Fruit et Pathologie, F-33882 Villenave d'Ornon, France; armelle.marais-colombel@inrae.fr

5 Centre de Coopération Internationale en Recherche Agronomique Pour le Développement, Unité Mixte de Recherche Amélioration Génétique et Adaptation des Plantes Méditerranéennes et Tropicales, F-97130 Capesterre Belle-Eau, France; pierre-yves.teycheney@cirad.fr

6 Amélioration Génétique et Adaptation des Plantes Méditerranéennes et Tropicales, Univ. Montpellier, Centre de Coopération Internationale en Recherche Agronomique Pour le Développement, Institut National de Recherche pour l'Agriculture, l'Alimentation et l'Environnement, Institut Agro, F-97130 Capesterre Belle-Eau, France

* Correspondence: marie.umber@inrae.fr; Tel.: +590-590-25-59-29

Received: 23 July 2020; Accepted: 25 September 2020; Published: 29 September 2020

\begin{abstract}
Yam (Dioscorea spp.) is an important crop in tropical and subtropical regions. Many viruses have been recently identified in yam, hampering genetic conservation and safe international exchanges of yam germplasm. We report on the implementation of reliable and cost-effective PCR-based detection tools targeting eight different yam-infecting viruses. Viral indexing of the in vitro yam collection maintained by the Biological Resources Center for Tropical Plants (BRC-TP) in Guadeloupe (French West Indies) unveiled a high prevalence of potyviruses, badnaviruses, Dioscorea mosaic associated virus (DMaV) and yam asymptomatic virus 1 (YaV1) and a high level of coinfections. Infected yam accessions were subjected to a combination of thermotherapy and meristem culture. Sanitation levels were monitored using PCR-based and high-throughput sequencing-based diagnosis, confirming the efficacy and reliability of PCR-based detection tools. Sanitation rates were highly variable depending on viruses. Sixteen accessions were successfully sanitized, paving the way to safe yam germplasm exchanges and the implementation of clean seed production programs worldwide.
\end{abstract}

Keywords: molecular diagnosis; yam; viruses; sanitation; germplasm conservation and dissemination 


\section{Introduction}

Yam is a staple food in the tropics and subtropics and the second most important tuber crop in Africa after cassava. Annual worldwide yam production was 73 million tons in 2018, with five African countries accounting for $92 \%$ of this production and Nigeria being the largest producer with 48 million tons [1]. Although worldwide yam production is increasing, yields are declining in some areas mostly due to decreasing soil fertility or attacks by pests and pathogens. In Guadeloupe (French West Indies), yam production has decreased by almost two thirds in 20 years, from $9000 \mathrm{t}$ in 1997 to $3425 \mathrm{t}$ in 2018 [1]. Hence, Guadeloupe is no longer self-sufficient and must import $80 \%$ of its yam tuber consumption needs. This steep decrease results from a combination of socio-economic and health factors such as the decrease of available cultivable lands, the increase in labor costs and the spread of pests and pathogens [2], especially viruses. For example, the American yam species Dioscorea trifida, originating from the Amazonian basin and once widely grown for local consumption, is almost no longer cultivated in Guadeloupe due to its high sensitivity to viruses [3]. Likewise, viral diseases strongly affect the production of African yam, D. rotundata, in West Africa, where it is a very popular crop [4] and plays an essential role in food security.

The overall high impact of viral diseases on yam production prompted efforts to identify yam-infecting viruses in order to design and implement control strategies based on accurate diagnosis and the production of clean seeds. These efforts led to the characterization of several novel viruses and/or the sequencing of the complete genomes belonging to genera Ampelovirus, Aureusvirus, Badnavirus, Carlavirus, Comovirus, Cucumovirus, Fabavirus, Macluravirus, Potexvirus and Potyvirus. Thus, within the last five years alone, the complete genomes of 13 novel yam viral species were sequenced: one potyvirus, Dioscorea mosaic virus (DMV, [5]); six badnaviruses, Dioscorea bacilliform AL virus 2 (DBALV2, [6]), Dioscorea bacilliform ES virus (DBESV, [6]), Dioscorea bacilliform RT virus 1 (DBRTV1, [7]), Dioscorea bacilliform RT virus 2 (DBRTV2, [7]), Dioscorea bacilliform RT virus 3 (DBRTV3, [8]) and Dioscorea bacilliform TR virus (DBTRV, [9]); one sadwavirus, Dioscorea mosaic associated virus (DMaV, [10]); two macluraviruses, Yam chlorotic mosaic virus (YCMV, [11]) and Yam chlorotic necrosis virus (YCNV, [12]); two ampeloviruses, Air potato ampelovirus 1 (AiPoV1, [5]) and yam asymptomatic virus 1 (YaV1, [13]) and one virus belonging to the family Betaflexiviridae, yam virus Y (YVY, [14]).

With more and more yam-infecting viruses being discovered, determining the viral status of yam germplasm has become increasingly challenging and critical to securing the safe production and exchange of genetic resources and preventing the spread of viral diseases. Indeed, international regulations prohibit the circulation of infected biological resources to avoid pathogenic outbreaks. For this, accurate and sensitive diagnosis tools and methods need to be developed and applied. Such tools and methods are also instrumental for the production of clean (virus-free) planting material produced by sanitation programs such as the one implemented by Guadeloupe's Biological Resource Center for Tropical Plants (BRC-TP). This program aims at producing virus-free yam plants through sanitation with respect to the viruses identified in Guadeloupe (Table 1). This germplasm collection includes accessions belonging to the five most cultivated tropical yam species (D. alata, D. bulbifera, D. cayenensis-rotundata, D. esculenta and D. trifida).

Table 1. List of yam-infecting viral species identified in Guadeloupe.

\begin{tabular}{ccccc}
\hline Family & Genus & Species & $\begin{array}{c}\text { Genbank Accession } \\
\text { Number of Complete } \\
\text { Genome }\end{array}$ & $\begin{array}{c}\text { Reference for } \\
\text { Presence of the Virus } \\
\text { in Guadeloupe }\end{array}$ \\
\hline Alphaflexiviridae & Potexvirus & $\begin{array}{c}\text { Yam virus X (YVX) } \\
\text { yam potexvirus 1 }\end{array}$ & $\begin{array}{c}\text { KJ711908 } \\
\text { Not determined }\end{array}$ & Not determined \\
\hline Bromoviridae & Cucumovirus & Cucumber mosaic virus (CMV) & KX008573 & KX430257 \\
\hline Caulimoviridae & Badnavirus & $\begin{array}{c}\text { Dioscorea bacilliform AL virus (DBALV) } \\
\text { Dioscorea bacilliform TR virus (DBTRV) }\end{array}$ & [15] \\
\hline Closteroviridae & Ampelovirus & yam asymptomatic virus 1 (YaV1) & MT409627 & [13] \\
\hline
\end{tabular}


Table 1. Cont.

\begin{tabular}{ccccc}
\hline Family & Genus & Species & $\begin{array}{c}\text { Genbank Accession } \\
\text { Number of Complete } \\
\text { Genome }\end{array}$ & $\begin{array}{c}\text { Reference for } \\
\text { Presence of the Virus } \\
\text { in Guadeloupe }\end{array}$ \\
\hline Potyviridae & Macluravirus & $\begin{array}{c}\text { Dioscorea alata macluravirus } \\
\text { Dioscorea esculenta macluravirus }\end{array}$ & $\begin{array}{c}\text { Not determined } \\
\text { Not determined }\end{array}$ & {$[17]$} \\
\hline \multirow{2}{*}{ Potyviridae } & Potyvirus & Yam mild mosaic virus (YMMV) & JX470965 & {$[18]$} \\
\hline Secoviridae & Sadwavirus & Dioscorea mosaic associated virus (DMaV) & KU215538, KU215539 & {$[19]$} \\
\hline
\end{tabular}

Several techniques have proved efficient in eliminating viruses from yams, such as chemotherapy, thermotherapy and cryotherapy associated with cell culture [21,22]. Alternative methods have been tested, like hot water treatment on vine cuttings, which resulted in 90\% of YMMV elimination [23], or more recently, treatment with ozone dissolved in water, which resulted in $63.5 \%$ of potyvirus elimination [24]. The BRC-TP has been using a combination of thermotherapy and meristem culture to eliminate YMV for almost 30 years [3]. However, virus elimination has been monitored by ELISA, a much less sensitive detection technique than commonly used RT-PCR-based detection. Hence, the success rate of this sanitation program needs to be assessed.

Here we report on the development of reliable and cost-effective molecular diagnostic tools for indexing all viruses occurring in yams in Guadeloupe and their implementation for virus prevalence studies. We present the first overall assessment of the efficiency of a yam sanitation process combining thermotherapy and meristem excision and the successful production of sanitized virus-free yam plants.

\section{Materials and Methods}

\subsection{Plant Material}

Plant material originated from the BRC-TP yam collection conserved in vitro in Guadeloupe and maintained in sterile conditions on solid growth medium (Table 2) at $24{ }^{\circ} \mathrm{C}$ under a photoperiod of $12 \mathrm{~h}$ [25]. A total of 396 accessions were used, including 140 accessions of D. alata, 4 D. bulbifera, 68 D. cayenensis-rotundata, 8 D. esculenta, 1 D. hurtiflora, 1 D. minutiflora, 1 D. nummularia, 1 D. pilimpika and 172 D. trifida. A detailed list of this plant material is provided in Table S1.

Table 2. Composition of the two media used in the sanitation process.

\begin{tabular}{cccc}
\hline & Growth Medium & & \multirow{2}{*}{ Regeneration Medium } \\
\cline { 1 - 3 } Components & D. alata and D. cayenensis-rotundata & D. trifida & \\
\hline MacroMS & $\mathrm{a}$ & $\mathrm{a}$ & $\mathrm{b}$ \\
MicroMS & $\mathrm{a}$ & $\mathrm{a}$ & $\mathrm{a}$ \\
FeEDTA & $\mathrm{a}$ & $\mathrm{a}$ & $\mathrm{a}$ \\
Morel vitamins & $\mathrm{c}$ & $\mathrm{c}$ & $\mathrm{c}$ \\
Sucrose & $30 \mathrm{~g} / \mathrm{L}$ & $30 \mathrm{~g} / \mathrm{L}$ & $30 \mathrm{~g} / \mathrm{L}$ \\
L-Glutamine & $200 \mathrm{mg} / \mathrm{L}$ & $200 \mathrm{mg} / \mathrm{L}$ & - \\
L-Glycine & - & $100 \mathrm{mg} / \mathrm{L}$ & - \\
Cysteine & $50 \mathrm{mg} / \mathrm{L}$ & - & - \\
BAP & $1 \mathrm{mg} / \mathrm{L}$ & $100 \mu \mathrm{g} / \mathrm{L}$ & $100 \mu \mathrm{g} / \mathrm{L}$ \\
Agar & $7 \mathrm{~g} / \mathrm{L}$ & $7 \mathrm{~g} / \mathrm{L}$ & $7 \mathrm{~g}$ \\
Activated charcoal & $2 \mathrm{~g} / \mathrm{L}$ & $2 \mathrm{~g} / \mathrm{L}$ & $2 \mathrm{~g}$ \\
\hline
\end{tabular}

a Composition described by Murashige and Skoog [26]; ${ }^{\mathrm{b}}$ Composition described by Murashige and Skoog [26], with quantity of components divided by two; ${ }^{\mathrm{C}}$ Composition described by Morel [27].

\subsection{Design of Primers for the Detection of DMaV, Yam Macluraviruses and Yam Potexviruses}

Nucleotide alignments were built from publicly available $\mathrm{DMaV}$ and yam macluraviruses genomic and EST sequences using the CLUSTALW component of Geneious (Biomatters Ltd., Auckland, New Zealand) in order to identify conserved regions in the genome of these viruses (Figure S1A,B). Primers were designed in conserved viral sequences encoding the RNA-dependent RNA polymerase (RdRp) of DMaV and the coat protein of the three yam macluraviruses (Table 3). Primers' specificity was monitored by direct sequencing of amplification products (Genewiz, Leipzig, Germany). 
Table 3. Sequence of primers and PCR parameters used in this study.

\begin{tabular}{|c|c|c|c|c|c|c|c|}
\hline Name & Targeted Virus or Gene & Sequence & Reference & $\begin{array}{c}\text { [Primers] } \\
(\mathrm{nM})\end{array}$ & $\begin{array}{l}{\left[\mathrm{MgCl}_{2}\right]} \\
(\mathrm{mM})\end{array}$ & $\begin{array}{c}\text { Annealing } \\
\text { Temperature }\left({ }^{\circ} \mathrm{C}\right)\end{array}$ & $\begin{array}{l}\text { Size of Amplification } \\
\text { Product }\end{array}$ \\
\hline $\begin{array}{l}\text { CMV1-F } \\
\text { CMV1-R }\end{array}$ & $\mathrm{CMV}^{\mathrm{a}}$ & $\begin{array}{c}\text { 5'-GTA GAC ATC TGT GAC GCG A-3' } \\
\text { 5'-GCG GGA AAC AAG CTT CTT ATC-3' }\end{array}$ & [28] & 400 & 1.5 & 55 & $540 \mathrm{bp}$ \\
\hline $\begin{array}{l}\text { Seco-1F } \\
\text { Seco-1R }\end{array}$ & $\mathrm{DMaV}^{\mathrm{a}}$ & $\begin{array}{l}5^{\prime} \text { AAC TCC WTC WGG WTT YGC TYT GAC } 3^{\prime} \\
5^{\prime} \text { CCC ACT TYC TYT TGA GAA AAT CAA } 3^{\prime}\end{array}$ & this study & 400 & 2 & 46 & $323 \mathrm{bp}$ \\
\hline $\begin{array}{l}\text { DiosClos-F } \\
\text { DiosClos-R }\end{array}$ & YaV1 ${ }^{a}$ & $\begin{array}{l}5^{\prime} \text { CTC TTT AGG TTT CCC ATT TAT CA } 3^{\prime} \\
5^{\prime} \text { TGG TTC TAC ATT ACT AGA CTA C } 3^{\prime}\end{array}$ & [13] & 800 & 2 & 49 & $285 \mathrm{bp}$ \\
\hline $\begin{array}{l}\text { YMV1 } \\
\text { YMV2 }\end{array}$ & YMV a & $\begin{array}{l}5^{\prime} \text { TGC GGA ACT CRA AAG AAC } 3^{\prime} \\
5^{\prime} \text { TGC CAT CAA ATC CAA ACA } 3^{\prime \prime}\end{array}$ & [29] & 200 & 3 & 53 & $196 \mathrm{bp}$ \\
\hline $\begin{array}{l}\text { YMMV CP 2F } \\
\text { YMMV UTR 1R }\end{array}$ & YMMV a & $\begin{array}{l}5^{\prime} \text { GGC ACA CAT GCA AAT GAA AGC } 3^{\prime} \\
5^{\prime} \text { CAC CAG TAG AGT GAA CAT AG } 3^{\prime}\end{array}$ & [30] & 300 & 3 & 53 & $249 \mathrm{bp}$ \\
\hline $\begin{array}{l}\text { YamMac4F } \\
\text { YamMac5R }\end{array}$ & Yam macluraviruses ${ }^{\text {b }}$ & $\begin{array}{l}5^{\prime} \text { CHG CAG CWA TYG GKM GTG 3' } \\
5^{\prime} \text { GGG TTG CTG AGC RTY GGA 3' }\end{array}$ & this study & 600 & 2 & 47 & $292 \mathrm{bp}$ \\
\hline $\begin{array}{l}\text { Potex-2RC } \\
\text { Potex-5 }\end{array}$ & Potexviruses $^{c}$ & $\begin{array}{c}5^{\prime} \text { AGC ATR GCN SCR TCY TG 3' } \\
5^{\prime} \text { CAY CAR CAR GCM AAR GAY GA } 3^{\prime}\end{array}$ & [31] & 400 & 2 & 49 & $584 \mathrm{bp}$ \\
\hline YamX-1F & Yam & 5' GAY ATT GGR GAY RTW YTI TTY WKG 3' & & & & & \\
\hline YamX-2F & Potexviruses ${ }^{b}$ & $5^{\prime}$ GRC ART CYC CAG ATT TYR AYH YRM A $3^{\prime}$ & & & & & \\
\hline YamX-3F ${ }^{d}$ & & 5’ CIC ART GGG TIA AGA AAR WKG A 3’ & this study & 300 & 2 & 43 & $255 \mathrm{bp}$ \\
\hline $\begin{array}{c}\text { YamX-4R } \\
\text { YamX-5R d }\end{array}$ & & $\begin{array}{l}5^{\prime} \text { CAT IAC AGT TTS TTG CAT RAA IG 3' } \\
5^{\prime}\end{array}$ & & & & & \\
\hline BadnaFP & Badnaviruses $^{c}$ & $5^{\prime}$ ATG CCI TTY GGI ITI AAR AAY GCI CC $3^{\prime}$ & [32] & 200 & 3 & 49 & $579 \mathrm{bp}$ \\
\hline BadnaRP & & $5^{\prime}$ CCA YTT RCA IAC ISC ICC CCA ICC $3^{\prime}$ & & & & & \\
\hline $\begin{array}{l}\text { atpB1 } \\
\text { atpB2 }\end{array}$ & atpB plastid gene & $\begin{array}{l}\text { 5' GGT CCT ATG ATT TCC ACA C } 3^{\prime} \\
5^{\prime} \text { CTT CAA TTT GTT CTC CAC } 3^{\prime}\end{array}$ & [33] & 200 & 3 & 49 & $1462 \mathrm{pb}$ \\
\hline
\end{tabular}

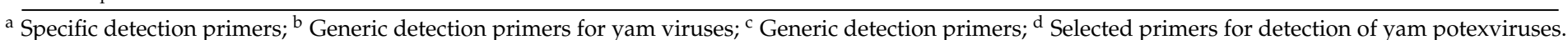


Likewise, the nucleotide sequences of 16 RNA-dependent RNA polymerase (RdRp) domains from isolates of the three potexvirus species reported in yams [15] were aligned as described above (Figure S1C). Five primers were designed in the conserved RdRp domain: three forward primers, YamX-1F, -2F and -3F; and two reverse primers, YamX-4R and -5R (Table 3). The specificity of primers YamX-3F and YamX-5R (Eurogentec, Angers, France) was assessed by sequencing amplification products generated from five infected plants using these primers (Table S1), following their cloning into pGEM-T easy vector (Promega, Charbonnières, France). A multiple alignment was performed on the sequences of the nine recombinant clones generated (deposited in GenBank under accession numbers MT632008-MT632016) and the corresponding 208 nt sequences described by Acina-Mambole et al. [15] using the CLUSTALW component of MEGA X [34]. Phylogenetic trees were constructed using the Maximum Likelihood method.

\subsection{Extraction of Total Nucleic Acids and Synthesis of cDNAs}

Total nucleic acids (TNAs) were extracted from $100 \mathrm{mg}$ leaf samples collected from yam plants according to the procedure 2 described by Foissac et al. [35], using a bead homogenizer (MP Biomedicals, Illkirch, France). cDNAs were generated as follows. First, $5 \mu \mathrm{L}$ of TNAs was denaturated for $5 \mathrm{~min}$ at $70{ }^{\circ} \mathrm{C}$, followed by a 5 min incubation on ice with $250 \mathrm{nM}$ of oligonucleotide Poly $_{6}$ and $125 \mathrm{nM}$ of oligonucleotide Polyt $\mathrm{T}_{18}$. Then, cDNA was synthetized for $1 \mathrm{~h}$ at $37^{\circ} \mathrm{C}$ with $500 \mu \mathrm{M}$ of dNTPs, $20 \mathrm{U}$ of RNAse inhibitor and $200 \mathrm{U}$ of the M-MLV reverse transcriptase (Promega).

\subsection{Detection of Yam Macluraviruses, CMV, DMaV, YaV1, YMV and YMMV by PCR}

PCR reactions were performed on $3 \mu \mathrm{L}$ of cDNAs with $200 \mu \mathrm{M}$ of dNTPs and 1.25 U GoTaq G2 polymerase (Promega). Primers and $\mathrm{MgCl}_{2}$ concentrations as well as annealing temperatures varied depending on the targeted virus and are detailed in Table 3. PCR conditions were an initial denaturation step of $2 \mathrm{~min}$ at $95^{\circ} \mathrm{C}$ and 30 cycles of $30 \mathrm{~s}$ at $95^{\circ} \mathrm{C}, 30 \mathrm{~s}$ at annealing temperature and $30 \mathrm{~s}$ at $72{ }^{\circ} \mathrm{C}$, followed by an elongation step of $5 \mathrm{~min}$ at $72{ }^{\circ} \mathrm{C}$, with appropriate control samples (infected and non-infected plants). Amplification products were analyzed by electrophoresis on a $1.2 \%$ agarose gel.

\subsection{Detection of Yam Potexviruses by Nested PCR}

A first PCR was performed on $3 \mu \mathrm{L}$ of cDNAs using the generic potexvirus-specific primer pair Potex-2RC/Potex-5 described by van der Vlugt and Berendsen [31]. A nested PCR was then performed on $1 \mu \mathrm{L}$ of the amplification products using YamX-3F/YamX-5R primers. PCR conditions were the same as those described above, and primers and $\mathrm{MgCl}_{2}$ concentrations as well as annealing temperatures are provided in Table 3. Amplification products were analyzed by electrophoresis on a $1.5 \%$ agarose gel.

\subsection{Detection of Badnaviruses by Multiplex-Immunocapture-PCR (M-IC-PCR)}

Badnavirus indexing was performed according to Le Provost et al. [36] with the following modifications. Microtubes $(0.2 \mu \mathrm{L})$ were coated with diluted polyclonal antibodies [37] during $48 \mathrm{~h}$ at $4{ }^{\circ} \mathrm{C}$, immunocapture was performed for $4 \mathrm{~h}$ at room temperature and samples were treated with 2 U of RQ1 DNAse (Promega) prior to PCR as described by Gambley et al. [38]. Multiplex-PCR was performed using generic badnavirus-specific primer pair BadnaFP/BadnaRP [32] and plant-genomic primer pair atpB1/atpB2 [33], with appropriate control samples (infected, non-infected plants and yam DNA), as described by Umber et al. [9] (Table 3). Amplification products were analyzed by electrophoresis on a $1 \%$ agarose gel.

\subsection{Sanitation Process}

Infected accessions were selected from the BRC-TP in vitro yam collection. They harbored various combinations of coinfection by yam viruses (DMaV, YaV1, YMV, YMMV, badnaviruses, 
macluraviruses and potexviruses; Table S2). Each infected accession was multiplied by cuttings into 24 vitroplants: 20 vitroplants were submitted to a first cycle of sanitation by thermotherapy and meristem culture (see below), and four were conserved as control mother plants. Regenerated vitroplants, called meriplants, were indexed for DMaV, YaV1, YMV, YMMV, badnaviruses, macluraviruses and potexviruses in order to assess the efficacy of the sanitation process. Then, virus-free meriplants were multiplied by cuttings, and two clones of each were acclimatized (see below) and indexed again for DMaV, YaV1, YMV, YMMV, badnaviruses, macluraviruses and potexviruses to ensure complete viral sanitation. Partially sanitized meriplants, i.e., still infected by one or more viruses, were submitted to additional sanitation cycles until the complete elimination of viruses. The sanitation process is detailed in Figure 1.

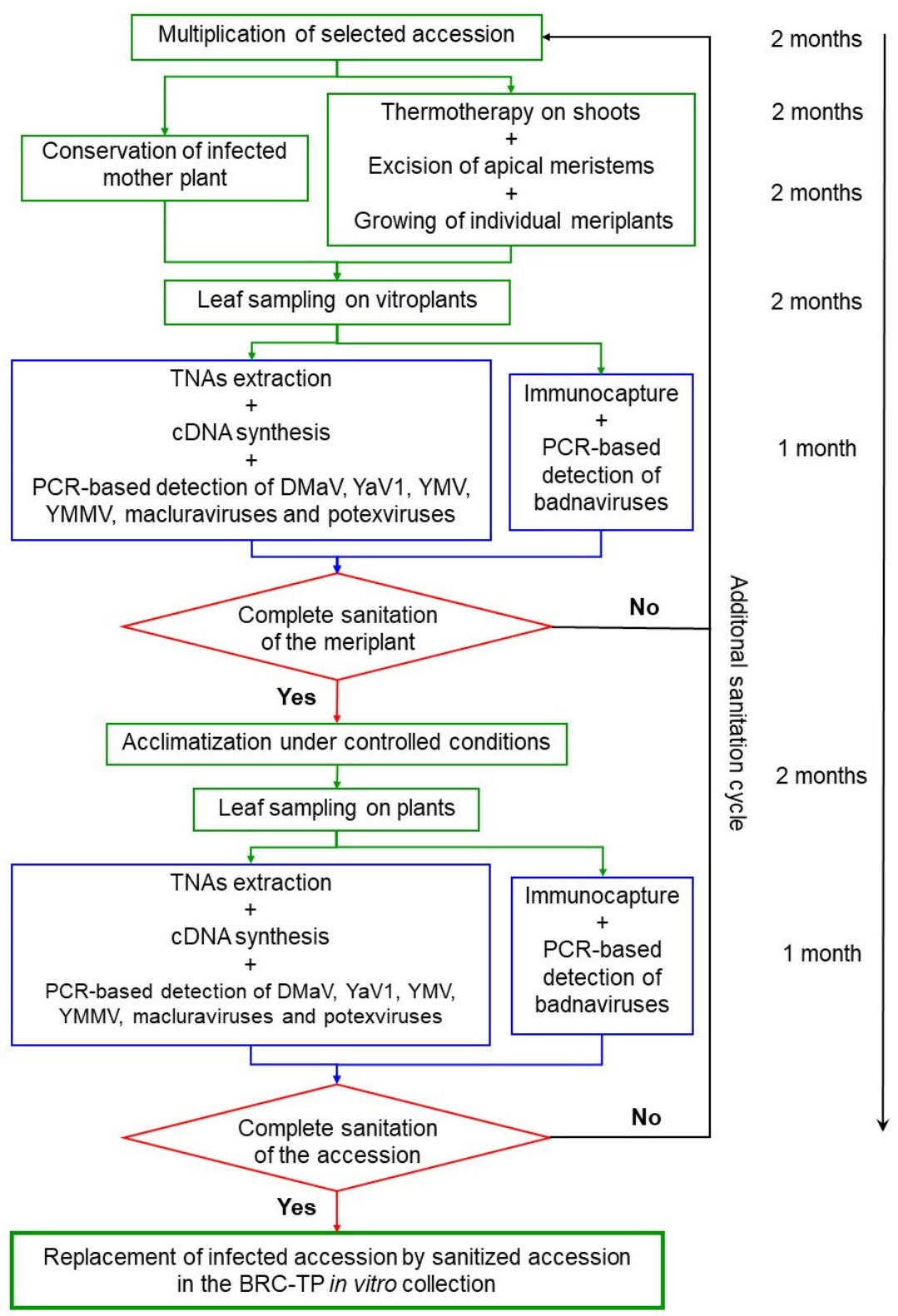

Figure 1. Flowchart of the sanitation process used in this work. Green boxes represent steps carried out in vitro or in controlled conditions; blue boxes represent molecular diagnosis steps; red diamonds represent decision steps. A timeline is provided. TNAs: total nucleic acids. 


\subsection{Thermotherapy and Meristem Excision of Yam Vitroplants}

Twenty shoots of selected infected vitroplant accessions were first maintained for two months on solid growth medium (Table 2 and Figure 2A) under sterile conditions at $34{ }^{\circ} \mathrm{C}$ and a photoperiod of $12 \mathrm{~h}$ in a thermal chamber (ST1 classic, Pol-EKO, Wodzisław Ślaski, Poland). Then, $1 \mathrm{~mm}$-sized apical meristems were excised under stereo microscope (Stemi 305, Zeiss, Marly-le-Roi, France) and grown in small Petri dishes on regeneration medium (Table 2) at $26{ }^{\circ} \mathrm{C}$ under a $12 \mathrm{~h}$ photoperiod (Figure $2 \mathrm{~B}$ ). Plantlets were transferred to growth medium in individual culture tubes upon the emergence of the first leaves and roots (Figure 2C). Once meriplants had grown at least four internodes, $100 \mathrm{mg}$ leaf samples were collected twice in two tubes containing lysis matrix A (MP Biomedicals, Illkirch, France) and stored at $-80^{\circ} \mathrm{C}$ until viral indexing.

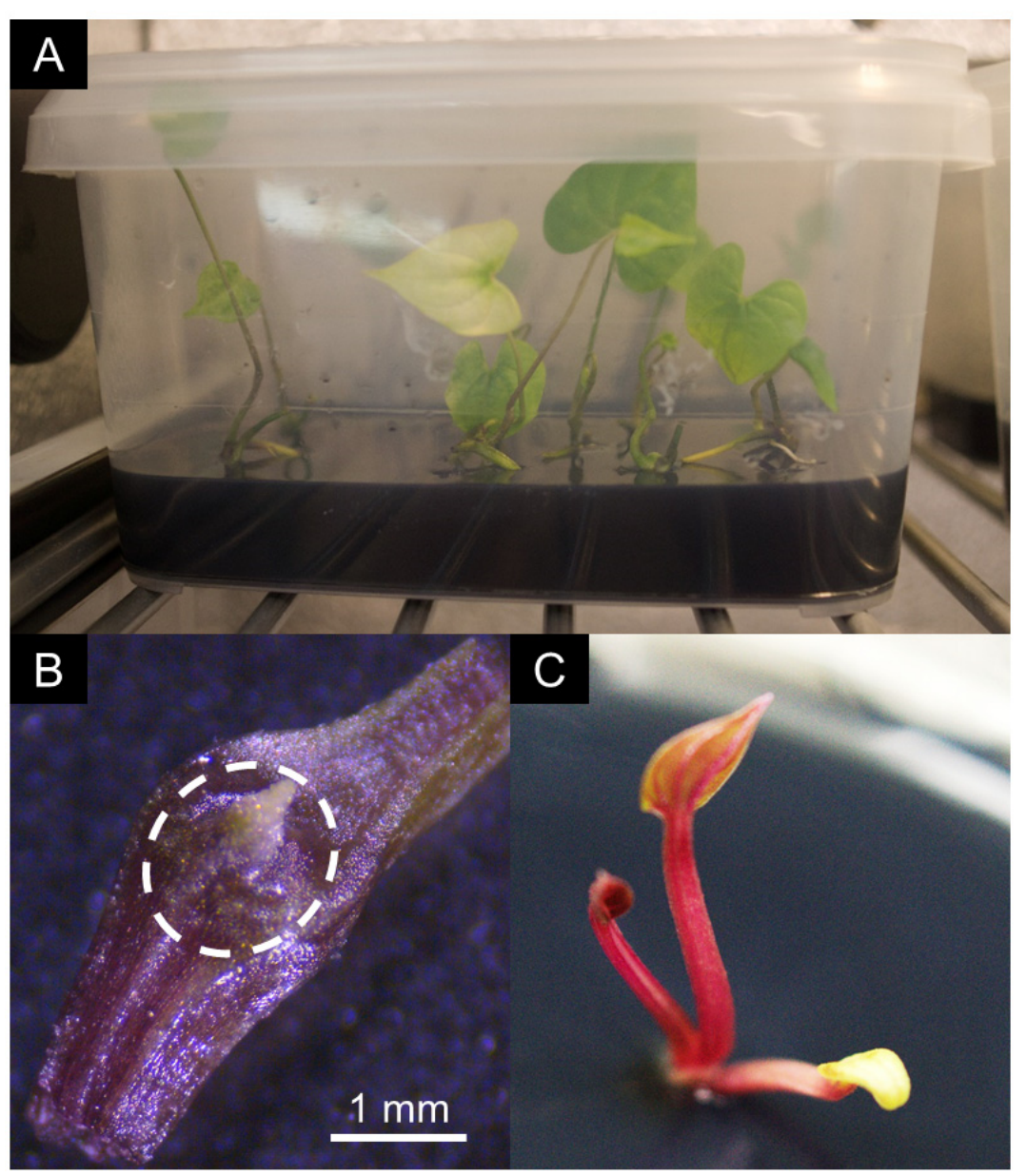

Figure 2. Illustration of in vitro steps of the sanitation process. (A) Dioscorea trifida cuttings inside a thermal chamber at $34{ }^{\circ} \mathrm{C}$. (B) Explant of D. trifida. The dotted white circle highlights the meristematic bud with leaf primordia. Scale of size is provided. (C) Plantlet of D. alata obtained from meristematic culture, called meriplant.

\subsection{Acclimatization of Yam Vitroplants}

Yam vitroplants were removed from tubes, cleaned from culture medium in water with a few drops of detergent and planted in small pots $(7 \times 7 \mathrm{~cm})$ filled with wet sterile potting soil 110/60/140 N/P/K (Plantaflor, Vechta, Germany). Pots were placed under homemade Plexiglas boxes in order to maintain moisture at as high a level as possible in a room with controlled conditions (12 h photoperiod, $26^{\circ} \mathrm{C}$ ). After 10 days, boxes were opened slightly, and after another 10 days, completely removed. When yam plantlets had grown approximately 20 leaves (about two months), two young 
well-developed leaves were collected, placed separately in two grinding bags (Universal $12 \times 15 \mathrm{~cm}$, Bioreba, Reinach, Switzerland) and stored at $-80^{\circ} \mathrm{C}$ until viral indexing.

\subsection{Assessment of Viral Sanitation by High-Throughput Sequencing-Based Viral Indexing}

Following acclimatization, two leaves from each of four sanitized D. trifida plantlets (278/TM1, 281/TM1, 528/TM1 and 650/TM2) were collected and processed independently. Double-stranded RNAs (dsRNAs) were purified from leaf samples and used for random amplification as described previously by Marais et al. [39]. Amplification products were then sequenced on the GeT-PlaGe platform (INRAE, Toulouse, France) for MiSeq sequencing $(2 \times 250 \mathrm{nt})$ in a multiplex scheme.

Sequencing reads were cleaned, demultiplexed [40] and assembled into contigs using the VirAnnot pipeline [41] and CLC Genomics Workbench 8.0 (Qiagen, Courtabœuf, France). Annotations were performed based on BLASTn and BLASTx comparisons [42]. Reads were also mapped on a selection of publicly available yam virus sequences retrieved from GenBank.

\section{Results}

\subsection{Implementation and Optimization of Viral Detection Tools}

In order to assess the viral status of the BRC-TP in vitro collection, we developed molecular diagnosis tools targeting yam-infecting viruses present in Guadeloupe (Table 1). Viruses with RNA genomes were detected by RT-PCR performed on total nucleic acids. For the detection of CMV, YaV1, YMV and YMMV, existing primers were used (Table 3). In contrast, no primers were readily available for the detection of $\mathrm{DMaV}$ and yam macluraviruses. Therefore, multiple alignments were built using sequences publicly available from GenBank, primers were designed in conserved domains (Figure S1A,B and Table 3) and used successfully for the detection of these viruses.

The use of existing generic primer pair Potex-2RC/Potex-5 [31] for the detection of yam potexviruses by RT-PCR resulted in nonspecific amplification products. Therefore, three forward primers (YamX-1F, YamX-2F, YamX-3F) and two reverse primers (YamX-4R, YamX-5R) were designed in the 584-nt region corresponding to the RdRp domain targeted by the primers designed by van der Vlugt and Berendsen [31], based on multiple alignments of yam virus X (YVX), yam potexvirus 1 and yam potexvirus 2 sequences (Figure S1C and Table 3). All primer combinations were tested. The most sensitive and reproducible results were obtained using primer pair YamX-3F and YamX-5R in nested PCR performed on an aliquot of RT-PCR products obtained using primer pair Potex-2RC/Potex-5. A selection of amplification products generated by YamX-3F/YamX-5R primers from two D. cayenensis-rotundata and five $D$. trifida accessions were cloned and sequenced (Table S1). The nine obtained sequences were compared to yam potexvirus sequences publicly available from GenBank, showing that they were most closely related to those of Yam virus X species (Figure S2).

The detection of badnaviruses was performed by M-IC-PCR to avoid false positives resulting from the amplification of endogenous Dioscorea bacilliform viruses (eDBVs), which are widespread in yam genomes [43].

All viral detection methods used in this work were optimized in order to increase their sensitivity and reliability, leading to optimal $\mathrm{MgCl}_{2}$ and primer concentrations as well as annealing temperatures, which are summarized in Table 3.

\subsection{Assessment of the Sanitary Status of the In Vitro BRC-TP Yam Collection}

Viral indexing was performed on 396 yam accessions of the in vitro yam collection conserved by the BRC-TP, using tools and methods described above for the detection of CMV, DMaV, YaV1, YMV, YMMV, badnaviruses, macluraviruses and potexviruses. The majority of sampled plants belonged to the five most cultivated yam species in Guadeloupe, Dioscorea alata (140 sampled plants), D. bulbifera (4), D. cayenensis-rotundata (68), D. esculenta (8) and D. trifida (172). Complete indexing results are provided in Table S1, and Figure 3A shows the prevalence of yam viruses registered for the 396 tested accessions 
and for the three most represented yam species in the collection, D. alata, D. cayenensis-rotundata and D. trifida.

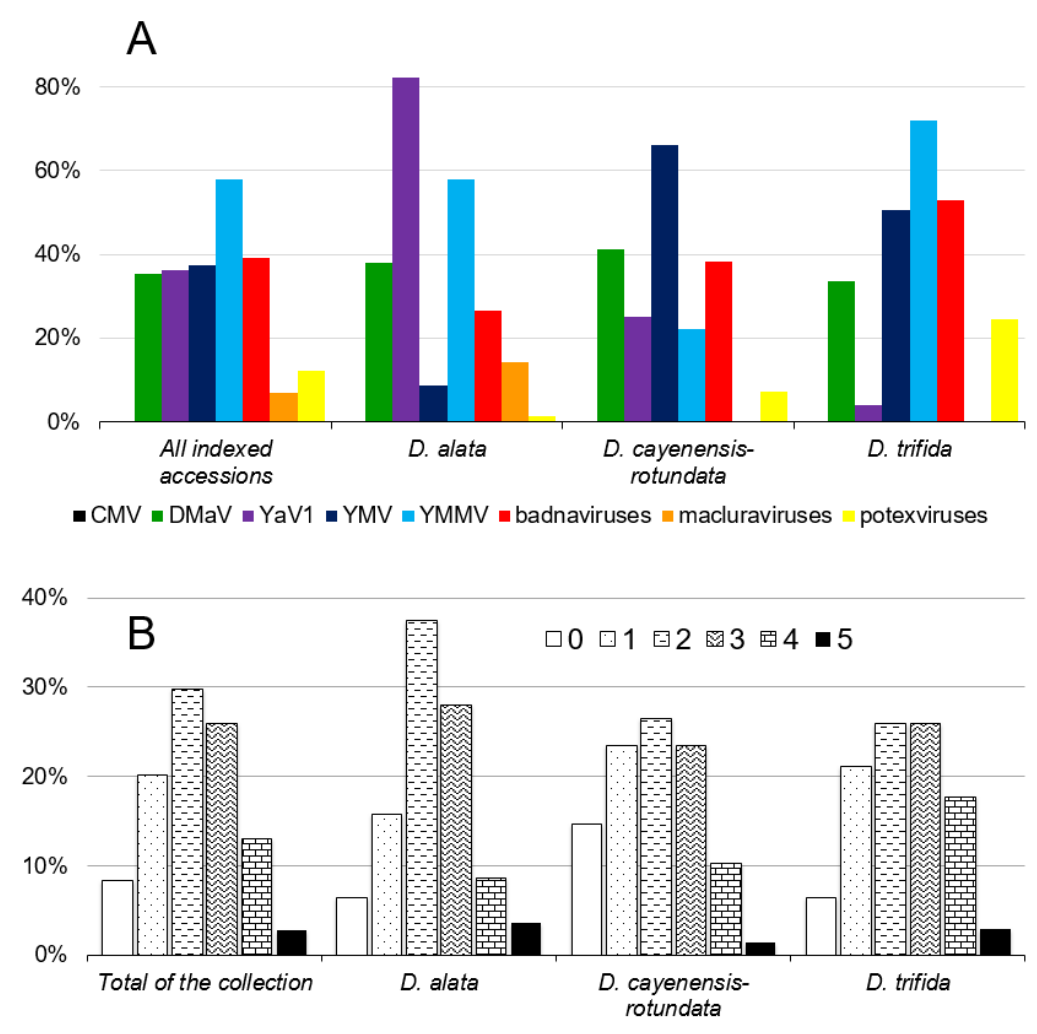

Figure 3. Results of viral indexing of the 396 tested accessions and the three most represented yam species (D. alata, D. cayenensis-rotundata and D. trifida) from the BRC-TP in vitro yam collection. (A) Prevalence of the eight yam viruses reported in Guadeloupe. CMV: cucumber mosaic virus; DMaV: Dioscorea mosaic associated virus; YaV1: yam asymptomatic virus 1; YMV: yam mosaic virus; YMMV: yam mild mosaic virus. (B) Percentage of accessions infected by 0, 1, 2, 3, 4 or 5 distinct viruses.

All targeted viruses were present in the in vitro BRC-TP collection, except CMV, despite samples being screened for the presence of this virus in separate experiments using two sets of primers that can detect strains and isolates of both CMV subgroups 1 and $2[44,45]$. Overall, YMMV was the most prevalent virus in the collection, with $57.8 \%$ (229/396) infected accessions. In contrast, macluraviruses displayed the lowest prevalence in the same collection, with only $7.1 \%(28 / 396)$ infected accessions. Prevalence for DMaV, YaV1, YMV and badnaviruses in the collection were very similar at $35.4 \%$ (140/396), 37.4\% (148/396), 36.4\% (144/396) and 39.2\% (154/393), respectively.

Mixed infections by up to five distinct viruses were reported in 282 accessions (71.2\%; Figure 3B, Table S1), whereas 33 accessions (8.3\%) were free from all targeted viruses. A majority of the indexed accessions was infected by two viruses $(29.5 \%, 117 / 396)$, whereas only a few $(11 / 396 ; 2.8 \%)$ were infected by five different viruses. Most of the coinfections involved combinations of YMV and YMMV, YMMV and badnaviruses, YMMV and YaV1, YMMV and DMaV or DMaV and badnaviruses.

\subsection{Sanitation of the BRC-TP In Vitro Yam Collection}

Viral detection tools were used to monitor the efficiency of sanitation. A total of 57 infected mother vitroplants from 10 accessions of $D$. alata, four of $D$. cayenensis-rotundata and 43 of $D$. trifida, representing all combinations of co-infection, were subjected to a sanitation cycle: 18 accessions were infected by DMaV, 10 by YaV1, 20 by YMV, 49 by YMMV, 26 by badnaviruses, six by macluraviruses and 12 by potexviruses (Table S2). Most accessions (41/57) were infected by more than one virus. Following thermotherapy and meristem culture, 285 meriplants were obtained, i.e., an average of five meriplants 
generated per mother plant, with a minimum of one and a maximum of 13 meriplants per mother plant (Table S2). On average, D. cayenensis-rotundata accessions showed the highest regeneration level (9.8), D. trifida the lowest (4.1) and D. alata an intermediate level (7.1).

Each meriplant and its mother plant were indexed twice for DMaV, YaV1, YMV, YMMV, badnaviruses, macluraviruses and potexviruses. No CMV indexing was performed since this virus could not be detected in the BRC-TP in vitro collection nor in the fields in Guadeloupe during viral prevalence studies [46]. After one cycle of sanitation, $44.9 \%$ of the meriplants (128/285, from 31 accessions) were partially sanitized and 14.4\% (41/285, from 17 accessions) were completely free from targeted viruses (Table S2).

Twelve non-sanitized or partially sanitized meriplants were subjected to a second cycle of sanitation (Table S2). A total of 66 meriplants were generated, leading to an average regeneration rate of 5.5 meriplants per accession. This second cycle of sanitation was less successful than the first one, leading to $48.5 \%$ partially sanitized meriplants (32/66, from five accessions) and only $4.5 \%$ virus-free meriplants (3/66, from two accessions), leading to a total of 44 virus-free meriplants.

\subsection{Assessment of the Sanitation in Acclimatized Plants}

Viral titers can be low in vitroplants, possibly below detection thresholds [47]. Therefore, sanitation of yam meriplants was further assessed in fully developed plants following acclimatization of vitroplants. For this, two clones of each fully sanitized meriplant were acclimatized and grown under controlled conditions, then indexed for DMaV, YaV1, YMV, YMMV, badnaviruses, macluraviruses and potexviruses once they reached a 20 leaves stage. Five meriplants died in the process, therefore 39 of the 44 sanitized meriplants could be assessed. Indexing results were identical for each meriplant pair and negative for all viruses for 36/39 meriplants corresponding to four $D$. alata accessions, one $D$. cayenensis-rotundata accession and 11 D. trifida accessions (Table 4). The three remaining meriplants were still infected by badnaviruses, $\mathrm{DMaV}$ or YMV, respectively (Table S2).

Table 4. List of sanitized meriplants.

\begin{tabular}{|c|c|c|c|c|}
\hline Common Name & Voucher ID & Yam Species & Meriplants $^{a}$ & Eliminated Viruses $^{b}$ \\
\hline Pacala station & PT-IG-00017 & D. alata & 35/TM1/TM1 c & $\mathrm{DMaV}+\mathrm{YaV} 1$ + macluraviruses \\
\hline Oriental & PT-IG-00074 & D. alata & $\begin{array}{l}\text { 93/TM1 } \\
\text { 93/TM5 }\end{array}$ & YaV1 + macluraviruses \\
\hline Toro & PT-IG-00078 & D. alata & 97/TM2 & YaV1 + YMMV + macluraviruses \\
\hline MH 22 & PT-IG-00164 & D. trifida & 278/TM1 d & $\mathrm{DMaV}+\mathrm{YMMV}$ \\
\hline 2.22 & PT-IG-00244 & D. trifida & $\begin{array}{l}\text { 281/TM1 }{ }^{d} \\
\text { 281/TM2 }\end{array}$ & YMMV \\
\hline Amoumbé 1 & PT-IG-00425 & D. trifida & $\begin{array}{l}\text { 489/TM3/TM2 }{ }^{\text {c }} \\
489 / \mathrm{TM} 3 / \mathrm{TM}^{\text {c }}\end{array}$ & YMV + YMMV + badnaviruses \\
\hline G. O 18 & PT-IG-00450 & D. trifida & $\begin{array}{c}\text { 514/TM7 } \\
\text { 514/TM8 } \\
\text { 514/TM10 } \\
\text { 514/TM11 } \\
\text { 514/TM12 }\end{array}$ & YMMV \\
\hline Jossaud 2 & PT-IG-00453 & D. trifida & 517/TM1 & $\mathrm{DMaV}+\mathrm{YMMV}+$ badnaviruses \\
\hline Marché Cayenne & PT-IG-00481 & D. trifida & 528/TM2 d & YMV \\
\hline 109 RA & PT-IG-00531 & D. cayenensis-rotundata & $\begin{array}{l}\text { 595/TM1 } \\
\text { 595/TM2 } \\
\text { 595/TM3 } \\
\text { 595/TM4 } \\
\text { 595/TM5 } \\
\text { 595/TM6 } \\
\text { 595/TM7 } \\
\text { 595/TM8 }\end{array}$ & YMV + badnaviruses \\
\hline
\end{tabular}


Table 4. Cont.

\begin{tabular}{|c|c|c|c|c|}
\hline Common Name & Voucher ID & Yam Species & Meriplants $^{a}$ & Eliminated Viruses $^{b}$ \\
\hline Tahiti couleuvre & PT-IG-00557 & D. alata & 621/TM3 & YaV1 + YMMV \\
\hline 3.45 & PT-IG-00585 & D. trifida & 650/TM1 d & YMV + YMMV + badnaviruses \\
\hline SM 23 & PT-IG-00650 & D. trifida & 715/TM2 & $\mathrm{DMaV}+\mathrm{YMV}+\mathrm{YMMV}$ \\
\hline Apatou 3 & PT-IG-00653 & D. trifida & $\begin{array}{l}\text { 718/TM1 } \\
\text { 718/TM2 }\end{array}$ & YMMV \\
\hline Saül 36 & PT-IG-00662 & D. trifida & 727/TM5 & badnaviruses \\
\hline St Jean 9 & PT-IG-00681 & D. trifida & $\begin{array}{l}\text { 746/TM2 } \\
\text { 746/TM4 } \\
\text { 746/TM5 } \\
\text { 746/TM7 } \\
\text { 746/TM8 } \\
\text { 746/TM9 }\end{array}$ & YMMV \\
\hline
\end{tabular}

a The code of meriplant name is composed by the number of the accession followed by "T", meaning thermotherapy, " $\mathrm{M}^{\prime}$, meaning meristem culture, and the number of the generated meriplant; ${ }^{\mathrm{b}}$ According to the indexation of the mother plant (Table S2); ${ }^{\mathrm{c}}$ These meriplants were sanitized after two cycles of sanitation; ${ }^{\mathrm{d}}$ the sanitation of these meriplants was confirmed by high throughput sequencing.

In order to confirm the results obtained using RT-PCR-based diagnostic, the virome of four fully sanitized D. trifida accessions was monitored by high throughput sequencing (HTS) of dsRNA [48]. For this, leaf samples were collected from the two acclimatized clones of these four accessions at the 20 leaves stage and analyzed. Prior to sanitation, these accessions were infected by YMV (accession 528), YMMV (accession 281), DMaV and YMMV (accession 278) or YMV, YMMV and badnaviruses (accession 650), respectively (Table S2). The number of demultiplexed cleaned reads was 19,378 for meriplant 278/TM1, 122,160 for meriplant 281/TM1, 102,474 for meriplant 528/TM2 and 92,674 for meriplant 650/TM1, respectively. After reads assembly and BLAST-based annotation of generated contigs, no contig related to ssRNA+ viruses that were initially present in the four yam accessions (YMV, YMMV and DMaV) could be identified. The analyses made by mapping of reads on YMV, YMMV and DMaV sequences were consistent with this result. Nevertheless, depending on samples, between 0 and 15 contigs were found to be related to mycoviruses or bacteriophages. The lack of sequences related to ssRNA+ viruses leads to the conclusion that the analyzed accessions were successfully sanitized for RNA viruses and confirms molecular indexing results.

Sanitation success rate is defined as the ratio of sanitized meriplants divided by the number of meriplants generated from an infected vitroplant. Sanitation success rates obtained in this work differed between viruses (Table 5), ranging from 14.5\% for YaV1 to 100\% for macluraviruses. Low sanitation success rates were obtained for badnaviruses (30.1\%), YMMV (24.9\%) and potexviruses $(18.9 \%)$. 
Table 5. Prevalence and sanitation rate of targeted viruses.

\begin{tabular}{|c|c|c|c|c|c|c|c|c|}
\hline Yam Species & Badnaviruses & CMV & DMaV & Macluraviruses & Potexviruses & YaV1 & YMV & YMMV \\
\hline D. alata & $6.6 \%(37 / 139)^{a}$ & $0.0 \%$ & $37.9^{\circ}$ & $0)$ & $1.4^{\circ}$ & $82.1^{\circ}$ & $8.6^{\circ}$ & $57.9 \%$ \\
\hline D. bulbifera & $25.0 \%(1 / 4)$ & $0.0 \%(0 / 4)$ & $25.0 \%(1 / 4)$ & $\%(1 / 4)$ & $0.0 \%$ & $0.0 \%$ & $25.0 \%$ & $0.0 \%$ \\
\hline D. cayenensis-rotundata & $38.2 \%(26 / 68)$ & $0.0 \%(0 / 68)$ & $41.2 \%(28 / 68)$ & $0.0 \%(0 / 68)$ & $7.4 \%(5 / 68)$ & $25.0 \%(17 / 68)$ & $66,2 \%(45 / 68)$ & $22,1 \%(15 / 68)$ \\
\hline D. trifida & $52.9 \%(90 / 170)$ & $0.0 \%(0 / 172)$ & $33.7 \%(58 / 172)$ & $0.0 \%(0 / 172)$ & $24.4 \%(42 / 172)$ & 4. $1 \%(7 / 172)$ & $50.6 \%(87 / 140)$ & $72.1 \%(124 / 172)$ \\
\hline Sanitation success rate & $30.1 \%(40 / 133)^{b}$ & $\mathrm{Na}^{\mathrm{c}}$ & $40.0 \%(50 / 122)$ & $100.0 \%(37 / 37)$ & $18.9 \%(17 / 90)$ & $14.5 \%(10 / 69)$ & $62.4 \%(53 / 85)$ & $24.9 \%(75 / 301)$ \\
\hline
\end{tabular}

a Percentage of infected accessions (number of infected accessions/total number of indexed accessions); ${ }^{b}$ Percentage of sanitized meriplants (number of sanitized meriplants/total number of meriplants generated from infected accessions); ${ }^{c}$ Not applicable. 


\section{Discussion}

Sexual reproduction provides natural sanitation for most plant viruses, which are not seed transmitted [49]. However, vegetatively propagated crops are deprived of this natural sanitation and accumulate viruses over time, hampering control strategies based on the production and use of clean seeds [50]. This paper reports on the development and optimization of diagnostic tools for the detection of viruses infecting yams and their successful implementation for the sanitation of yam accessions, resulting in virus-free yam germplasm and paving the way to a better control of yam-infecting viruses.

A comprehensive diagnostic strategy was designed in order to increase sensitivity and to reduce costs and labor. Extraction of high quality TNAs from yam was achieved using the method developed by Foissac et al. [35]. This method is based on the use of silica in order to remove polyphenolic and mucilaginous compounds, which are naturally present in high amounts in yam and hamper the purification of high quality nucleic acids and their long-term conservation [51]. Universal primers were used to prime the synthesis of cDNAs from TNAs, resulting in versatile templates that could be used for the detection of all yam viruses by PCR, except for badnaviruses, which were detected by M-IC-PCR to avoid false positives resulting from the presence of eDBVs in the genome of yams. Existing primers were used for the detection of CMV, YaV1, YMV, YMMV and badnaviruses, whereas new primers were designed for the detection of more recently characterized viruses such as $\mathrm{DMaV}$, macluraviruses and potexviruses (Table 3). PCR conditions were optimized for all primer combinations used in this work, resulting in accurate sensitivity and specificity. HTS performed on sanitized plants confirmed the results obtained by RT-PCR-based tests, demonstrating the accuracy of the molecular detection tools developed in this study. However, although the use of dsRNA templates for HTS proved successful for the detection of RNA viruses in yam [13], it is not appropriate for the detection of DNA viruses. Therefore, the presence in the analyzed sanitized plants of residual badnaviruses below the threshold of detection by M-IC-PCR cannot be ruled out.

Several potexviruses have been reported in yams [15]. Degenerate primers designed by van der Vlugt and Berendsen [31] were successfully used to detect potexviruses in several crops. However, these primers generated non-specific amplification products when used in yams, resulting in unreliable diagnosis. Based on the alignment of nucleotide sequences in the polymerase domain of all known yam potexviruses, a new set of primers was designed (Table 3) and used in RT-nested-PCR experiments, providing accurate, reliable and reproducible diagnosis. Such nested PCR is successfully used for the detection of other viruses in the families Alphaflexiviridae and Betaflexiviridae, whose members are difficult to detect by RT-PCR [35,52]. Indexing confirmed that only one of the three potexviruses reported in yams, yam virus $X$, is present in the BRC-TP yam collection [15].

Taking advantage of the above-mentioned comprehensive diagnostic tools, we undertook the first large-scale virus prevalence study in a yam germplasm collection. The indexing of 396 accessions conserved by the BRC-TP showed that $91.6 \%$ (363/396) of these accessions were infected by at least one virus and $71.5 \%$ of them were co-infected by two to five viruses, demonstrating that viruses could easily coexist in the yam plant (Figure 3B and Table S1).

Potyviruses displayed the highest prevalence in the analyzed yam collection, with $71 \%$ of the accessions (281/396) infected by YMV and/or YMMV (Figure 3A and Table S1). Prevalence of potyviruses was $60 \%$ in D. alata, $25 \%$ in D. bulbifera, $73.5 \%$ in D. cayenensis-rotundata, $87.5 \%$ in D. esculenta and $79.1 \%$ in D. trifida. Potyviruses cause severe damage in a wide range of crops [53] including yams [54], therefore such a high infection rate threatens the long term conservation of the BRC-TP yam collection.

Surprisingly, none of the accessions were infected by CMV, although this virus has one of the broadest host spectrum ranges among plant viruses [55]. CMV was detected in yam in sub-Saharan Africa with a low prevalence [56,57], and viral particles of CMV were reported in yam in Guadeloupe [16]. However, the virus could not be detected by molecular tests despite numerous attempts using several sets of primers, suggesting that isometric particles of another yam-infecting virus such as DMaV were confused with CMV virions or that available molecular detection tools are not able to detect CMV isolates that may be present in Guadeloupe. 
Significant differences in virus prevalence were observed between yam species (Figure 3A and Table 5). For example, D. alata accessions were mostly infected by YaV1 and/or YMMV, whereas $D$. cayenensis-rotundata accessions were mostly infected by $\mathrm{YMV}$, D. esculenta by macluraviruses and/or YaV1, and D. trifida by YMMV, badnaviruses and/or YMV. Overall, YMV was mostly detected in D. cayenensis-rotundata and D. trifida accessions, YMMV in D. alata and D. trifida accessions, YaV1 in D. alata and D. esculenta accessions, potexviruses in D. trifida accessions and macluravirus in D. esculenta accessions (Table 5). On the contrary, macluraviruses were not detected in D. cayenensis-rotundata and D. trifida accessions, and prevalence of $\mathrm{DMaV}$ and badnaviruses was similar among yam species.

The sanitation method described in this work involves a combination of thermotherapy and meristem culture. Thermotherapy allows the reduction of the viral replication rate in vascularized tissues and meristem excision favors the regeneration of healthy plantlets from virus-free totipotent cells. This combination proved moderately efficient on the vitroplants used in this work, since only 36 out of 351 generated meriplants $(9.7 \%)$ were fully sanitized, representing 16 of the 57 accessions subjected to sanitation (Table 4). Comparatively, $100 \%$ and $52.4 \%$ of sweet potato plantlets infected by sweet potato feathery mottle virus (SPFMV, genus Potyvirus) and sweet potato leaf curl virus (SPLCV, genus Begomovirus), respectively, were sanitized by the combination of thermotherapy and meristem excision [58,59]. The low rate of sanitation success in yam may result from the small size of yam meristems, which are particularly difficult to excise without surrounding contaminated cells, even following thermotherapy (Figure 2B). Our work also shows that the efficiency of the sanitation process varies between viruses, ranging from $14.5 \%$ for YaV1 to $100 \%$ for macluraviruses (Table 5). This difference could result from differential sensitivities to high temperatures among yam-infecting viruses and/or their cellular localization.

It is important to stress out that the meriplants considered as virus-free in our work are sanitized only for the viruses for which optimized diagnosis tools are currently available, with the exception of the four plants assessed by HTS. Therefore, the sanitation scheme reported in this paper does not yet include recently characterized yam viruses such as AiPoV1, DMV and YVY, for which molecular diagnostic tools are being developed. However, the sanitation process reported in this work (Figure 1) has been designed to accommodate the diagnosis of additional viruses upon the implementation of detection tools targeting these viruses. This process is therefore similar in essence to more global initiatives such as the one developed for other vegetatively propagated crops such as Rubus spp [60]. However, the approach we developed purposely does not include the systematic use of HTS in our evaluation pipeline (Figure 1) because the methods and approaches described in this paper are meant to be used in yam germplasm repositories that are often located in developing countries where access to HTS is difficult and expensive. Overall, the use of HTS for routine diagnosis on a large number of plants is not cost effective and should be reserved for confirming the viral status at the very end of the sanitation process, as suggested by Bömer et al. [61].

Sanitation is a long and time-consuming process: a complete sanitation cycle takes up to nine months, not including the whole plant verification step (Figure 1). Hence, sanitation should be streamlined in order to focus on pathogenic viruses. Meanwhile, an increasing number of novel viruses are reported in yam, based on HTS data $[5,13,62]$. There is a need to assess their symptomatology, biology, epidemiology and impact on yam production in order to decide whether they are worth including in sanitation programs. Replacing thermotherapy by cryotherapy could also help alleviating sanitation costs and labor since cryotherapy consists in instant deep freezing of bud tissues and results in the destruction of infected vascularized tissues surrounding virus-free meristematic cells, thus enabling the regeneration of sanitized plantlets [63]. When applied to axillary buds of white yam (Dioscorea rotundata Poir.), this approach led to the regeneration of $70 \%$ virus-free plants from YMV-infected plants [14]. This sanitation success rate is very similar to that obtained by the method described in this paper (62.7\%) therefore cryotherapy should be evaluated on other yam species and yam-infecting viruses. 
Supplementary Materials: The following are available online at http:/www.mdpi.com/1999-4915/12/10/1101/s1. Table S1: Results of indexing in the BRC-TP in vitro collection for the eight viruses previously reported in in Guadeloupe; Table S2: Results of indexing for viruses detected from in vitro yam collection in mother plants and meriplants generated after one cycle of sanitation, two cycles of sanitation and verification on acclimatized plants. Figure S1: Design of the primers used for the detection of DMaV, macluraviruses and potexviruses. Figure S2. Maximum likelihood phylogenetic tree of partial nucleotide sequences amplified from yam potexviruses using primers YamX-3F and YamX-5R.

Author Contributions: Conceptualization, M.U., D.F. and F.G.; Formal analysis, M.U., S.G. (Suzia Gélabale), R.-M.G., A.M. and S.G. (Séverine Gallet); Funding acquisition, C.P. and P.-Y.T.; Supervision, C.P. and P.-Y.T.; Validation, M.U., A.M. and P.-Y.T.; Writing—original draft, M.U.; Writing—review and editing, M.U., D.F., A.M. and P.-Y.T. All authors have read and agreed to the published version of the manuscript.

Funding: This work was funded by INRAE, the French government, the Guadeloupe Region and the European Union through Caramba (N 32920), CRBio (CRB PT 23092015) and Malin (2015-FED-187) projects.

Acknowledgments: The authors wish to thank Anthony Génipa, Bénédicte Bique, Laura Pazzé, Logane Péroumalnaiik and Odile Umber (INRAE, Petit-Bourg, Guadeloupe) for technical help, as well as Chantal Faure (INRAE, Villenave d'Ornon, France), and the GeT-PlaGe platform (INRAE, Toulouse, France) for MiSeq sequencing.

Conflicts of Interest: The authors declare no conflict of interest.

\section{References}

1. FAOSTAT. Available online: http://www.fao.org/faostat/ (accessed on 20 May 2020).

2. Barlagne, C.; Cornet, D.; Blazy, J.M.; Diman, J.L.; Ozier-Lafontaine, H. Consumers' preferences for fresh yam: A focus group study. Food Sci. Nutr. 2017, 5, 54-66. [CrossRef] [PubMed]

3. Saleil, V.; Degras, L.; Jonard, R. Obtention de plantes indemnes du virus de la mosaïque de l'igname (YMV) par culture in vitro des apex chez l'igname américaine Dioscorea trifida L. Agronomie 1990, 10, 605-615. [CrossRef]

4. Thouvenel, J.C.; Dumont, R. Perte de rendement de l'igname infectée par le virus de la mosaïque en Côte d'Ivoire. Agron. Trop. 1990, 45, 125-129.

5. Dey, K.K.; Sugikawa, J.; Kerr, C.; Melzer, M.J. Air potato (Dioscorea bulbifera) plants displaying virus-like symptoms are co-infected with a novel potyvirus and a novel ampelovirus. Virus Genes 2019, 55, 117-121. [CrossRef]

6. Sukal, A.; Kidanemariam, D.; Dale, J.L.; James, A.; Harding, R.M. Characterization of badnaviruses infecting Dioscorea spp. in the Pacific reveals two putative novel species and the first report of Dioscorea bacilliform RT virus 2. Virus Res. 2017, 238, 29-34. [CrossRef]

7. Bömer, M.; Turaki, A.A.; Silva, G.; Kumar, P.L.; Seal, S.E. A sequence-independent strategy for amplification and characterisation of episomal badnavirus sequences reveals three previously uncharacterised yam badnaviruses. Viruses 2016, 8, 188. [CrossRef]

8. Bömer, M.; Rathnayake, A.I.; Visendi, P.; Silva, G.; Seal, S.E. Complete genome sequence of a new member of the genus Badnavirus, Dioscorea bacilliform RT virus 3, reveals the first evidence of recombination in yam badnaviruses. Arch. Virol. 2018, 163, 533-538. [CrossRef]

9. Umber, M.; Gomez, R.M.; Gélabale, S.; Bonheur, L.; Pavis, C.; Teycheney, P.Y. The genome sequence of Dioscorea bacilliform TR virus, a member of the genus Badnavirus infecting Dioscorea spp., sheds light on the possible function of endogenous Dioscorea bacilliform viruses. Arch. Virol. 2017, 162, 517-521. [CrossRef]

10. Hayashi, E.A.I.; Blawid, R.; de Melo, F.L.; Andrade, M.S.; Pio-Ribeiro, G.; de Andrade, G.P.; Nagata, T. Complete genome sequence of a putative new secovirus infecting yam (Dioscorea) plants. Arch. Virol. 2017, 162, 317-319. [CrossRef]

11. Zhang, P.; Peng, J.; Guo, H.; Chen, J.; Chen, S.; Wang, J. Complete genome sequence of yam chlorotic necrotic mosaic virus from Dioscorea parviflora. Arch. Virol. 2016, 161, 1715-1717. [CrossRef] [PubMed]

12. Lan, P.; Meng, Y.; Shen, P.; Li, R.; Ma, Y.; Tan, S.; Chen, H.; Cao, M.; Li, F. Complete genome sequence of yam chlorotic necrosis virus, a novel macluravirus infecting yam. Arch. Virol. 2018, 163, 2275-2278. [CrossRef] [PubMed]

13. Marais, A.; Umber, M.; Filloux, D.; Gomez, R.-M.; Faure, C.; Pavis, C.; Julian, C.; Roumagnac, P.; Acina-Mambole, I.; Bonheur, L.; et al. Yam asymptomatic virus 1, a novel virus infecting yams (Dioscorea spp.) with significant prevalence in a germplasm collection. Arch. Virol. 2020. [CrossRef] [PubMed] 
14. Silva, G.; Bömer, M.; Rathnayake, A.I.; Sewe, S.O.; Visendi, P.; Oyekanmi, J.O.; Quain, M.D.; Akomeah, B.; Kumar, P.L.; Seal, S.E. Molecular characterization of a new virus species identified in yam (Dioscorea spp.) by high-throughput sequencing. Plants 2019, 8, 167. [CrossRef] [PubMed]

15. Acina-Mambole, I.; Bonheur, L.; Svanella-Dumas, L.; Filloux, D.; Gomez, R.M.; Faure, C.; Lange, D.; Anzala, F.; Pavis, C.; Marais, A.; et al. Molecular characterization of yam virus X, a new potexvirus infecting yams (Dioscorea spp.) and evidence for the existence of at least three distinct potexviruses infecting yams. Arch. Virol. 2014, 159, 3421-3426. [CrossRef] [PubMed]

16. Migliori, A. Maladie A Virus De L'Igname (Dioscorea sp.). In Proceedings of the 14th Annual Meeting of the Caribbean Food Crops Society, Guadeloupe and Martinique, France, 27 June-2 July 1977; pp. 428-435.

17. Filloux, D.; Bonheur, L.; Umber, M.; Pavis, C.; Fernandez, E.; Galzi, S.; Julian, C.; Daugrois, J.H.; Sukal, A.; Winter, S.; et al. Metagenomic discovery, worldwide distribution and genetic diversity of novel macluraviruses infecting yams (Dioscorea spp.). In Proceedings of the 15èmes Rencontres de Virologie Végétale, Aussois, France, 18-22 January 2015; p. 86.

18. Bousalem, M.; Dallot, S.; Fuji, S.; Natsuaki, K.T. Origin, world-wide dispersion, bio-geographical diversification, radiation and recombination: An evolutionary history of Yam mild mosaic virus (YMMV). Infect. Genet. Evol. 2003, 3, 189-206. [CrossRef]

19. Bousalem, M.; Douzery, E.J.P.; Fargette, D. High genetic diversity, distant phylogenetic relationships and intraspecies recombination events among natural populations of Yam mosaic virus: A contribution to understanding potyvirus evolution. J. Gen. Virol. 2000, 81, 243-255. [CrossRef]

20. Acina-Mambole, I.; Bonheur, L.; Anzala, F.; Gomez, R.M.; Lange, D.; Faure, C.; Marais, A.; Pavis, C.; Roumagnac, P.; Filloux, D.; et al. Characterization and diagnostic of Yam virus X (YVX) and Yam necrosis virus (YNV), two novel viruses infecting yams in Guadeloupe. In Proceedings of the 14èmes Rencontres de Virologie Végétales, Aussois, France, 13-17 January 2013; p. 57.

21. Filloux, D.; Girard, J.C. Indexing and elimination of viruses infecting yams (Dioscorea spp.) for the safe movement of germplasm. In Proceedings of the 14th Triennial Symposium of the International Society for Tropical Root Crop, Thiruvananthapuram Kerala, India, 20-26 November 2006; p. 13.

22. Ita, E.E.; Uyoh, E.A.; Nakamura, I.; Ntui, V.O. Efficient elimination of Yam mosaic virus (YMV) from white yam (Dioscorea rotundata Poir.) by cryotherapy of axillary buds. S. Afr. J. Bot. 2020, 130, 123-129. [CrossRef]

23. Jayaseelan, D.; Rajitha, M.; Dhanya, M.K.; Hegde, V.; Jeeva, M.L. Hot water treatment: An efficient method for elimination of Yam mild mosaic virus in Dioscorea alata. J. Root Crops 2011, 37, 60-64.

24. González Ramírez, J.E.; Jova, M.C.; Robaina, A.; Rodríguez Peréz, D.; González Cadalso, A.; Portal, O. Water-dissolved ozone mediates potyvirus sanitation during in vitro propagation of Dioscorea cayenensis subsp. Rotundata (Poir.) Miège. Ozone Sci. Eng. 2020, 42, 89-94. [CrossRef]

25. Mantell, S.H.; Hugo, S.A. Effects of photoperiod, mineral medium strength, inorganic ammonium, sucrose and cytokinin on root, shoot and microtuber development in shoot cultures of Dioscorea alata L. and D. bulbifera L. yams. Plant Cell Tiss. Org. 1989, 16, 23-37. [CrossRef]

26. Murashige, T.; Skoog, F. A revised medium for rapid growth and bio assays with tobacco tissue cultures. Physiol. Plant. 1962, 15, 473-497. [CrossRef]

27. Morel, G. Sur la culture des tissus de 2 Monocotylédones. C. R. Hebd. Séances Acad. Sci. 1950, 230, $1099-1101$.

28. De Blas, C.; Borja, M.J.; Saiz, M.; Romero, J. Broad spectrum detection of cucumber mosaic virus (CMV) using the polymerase chain reaction. J. Phytopathol. 1994, 141, 323-329. [CrossRef]

29. Bousalem, M.; Dallot, S.; Guyader, S. The use of phylogenetic data to develop molecular tools for the detection and genotyping of Yam mosaic virus. Potential application in molecular epidemiology. J. Virol. Methods 2000, 90, 25-36. [CrossRef]

30. Mumford, R.A.; Seal, S.E. Rapid single-tube immunocapture RT-PCR for the detection of two yam potyviruses. J. Virol. Methods 1997, 69, 73-79. [CrossRef]

31. Van der Vlugt, R.A.A.; Berendsen, M. Development of a general potexvirus detection method. Eur. J. Plant Pathol. 2002, 108, 367-371. [CrossRef]

32. Yang, I.C.; Hafner, G.J.; Revill, P.A.; Dale, J.L.; Harding, R.M. Sequence diversity of South Pacific isolates of Taro bacilliform virus and the development of a PCR-based diagnostic test. Arch. Virol. 2003, 148, 1957-1968. [CrossRef]

33. Soltis, P.S.; Soltis, D.E.; Chase, M.W. Angiosperm phylogeny inferred from multiple genes as a tool for comparative biology. Nature 1999, 402, 402-404. [CrossRef] 
34. Kumar, S.; Stecher, G.; Li, M.; Knyaz, C.; Tamura, K. MEGA X: Molecular Evolutionary Genetics Analysis across computing platforms. Mol. Biol. Evol. 2018, 35, 1547-1549. [CrossRef]

35. Foissac, X.; Svanella-Dumas, L.; Gentit, P.; Dulusq, M.J.; Marais, A.; Candresse, T. Polyvalent degenerate oligonucleotides reverse transcription-polymerase chain reaction: A polyvalent detection and characterization tool for trichoviruses, capilloviruses, and foveaviruses. Phytopathology 2005, 95, 617-625. [CrossRef]

36. Le Provost, G.; Iskra-Caruana, M.L.; Acina, I.; Teycheney, P.Y. Improved detection of episomal Banana streak viruses by multiplex immunocapture PCR. J. Virol. Methods 2006, 137, 7-13. [CrossRef] [PubMed]

37. Ndowora, T.; Dahal, G.; LaFleur, D.; Harper, G.; Hull, R.; Olszewski, N.E.; Lockhart, B.E. Evidence that badnavirus infection in Musa can originate from integrated pararetroviral sequences. Virology 1999, 255, 214-220. [CrossRef] [PubMed]

38. Gambley, C.F.; Geering, A.D.W.; Steele, V.; Thomas, J.E. Identification of viral and non-viral reverse transcribing elements in pineapple (Ananas comosus), including members of two new badnavirus species. Arch. Virol. 2008, 153, 1599-1604. [CrossRef] [PubMed]

39. Marais, A.; Faure, C.; Bergey, B.; Candresse, T. Viral double-stranded RNAs (dsRNAs) from plants: Alternative nucleic acid substrates for high-throughput sequencing. In Viral Metagenomics; Pantaleo, V., Chiumenti, M., Eds.; Humana Press: New York, NY, USA, 2008; pp. 45-53. [CrossRef]

40. Candresse, T.; Marais, A.; Faure, C.; Gentit, P. Association of Little cherry virus 1 (LChV1) with the Shirofugen stunt disease and characterization of the genome of a divergent LChV1 isolate. Phytopathology 2013, 103, 293-298. [CrossRef]

41. Lefebvre, M.; Theil, S.; Ma, Y.; Candresse, T. The VirAnnot pipeline: A resource for automated viral diversity estimation and operational taxonomy units assignation for virome sequencing data. Phytobiomes J. 2019, 3, 256-259. [CrossRef]

42. Altschul, S.F.; Gish, W.; Miller, W.; Myers, E.W.; Lipman, D.J. Basic local alignment search tool. J. Mol. Biol. 1990, 215, 403-410. [CrossRef]

43. Umber, M.; Filloux, D.; Muller, E.; Laboureau, N.; Galzi, S.; Roumagnac, P.; Iskra-Caruana, M.L.; Pavis, C.; Teycheney, P.Y.; Seal, S.E. The genome of African yam (Dioscorea cayenensis-rotundata complex) hosts endogenous sequences from four distinct badnavirus species. Mol. Plant Pathol. 2014, 15, 790-801. [CrossRef]

44. Wylie, S.; Wilson, C.R.; Jones, R.A.C.; Jones, M.G.K. A polymerase chain reaction assay for cucumber mosaic virus in lupin seeds. Aust. J. Agr. Res. 1993, 44, 41-51. [CrossRef]

45. Hu, J.S.; Li, H.P.; Barry, K.; Wang, M.; Jordan, R. Comparison of dot blot, ELISA, and RT-PCR assays for detection of two cucumber mosaic virus isolates infecting banana in Hawaii. Plant Dis. 1995, 79, 902-906. [CrossRef]

46. Diouf, M.B. INRAE/CIRAD, Petit-Bourg, Guadeloupe, France, Prevalence studies in the fields in Guadeloupe. Not published. 2020.

47. Spiegel, S. Problems associated with in vitro culture propagation and virus detection. In Proceedings of the 11th International Symposium on Virus Diseases of Ornamental Plants, Taichung, Taiwan, 9-14 March 2004; Volume 722, pp. 79-82. [CrossRef]

48. Massart, S.; Olmos, A.; Jijakli, H.; Candresse, T. Current impact and future directions of high throughput sequencing in plant virus diagnostics. Virus Res. 2014, 188, 90-96. [CrossRef]

49. Johansen, E.; Edwards, M.C.; Hampton, R.O. Seed transmission of viruses: Current perspectives. Annu. Rev. Phytopathol. 1994, 32, 363-386. [CrossRef]

50. Van den Bosch, F.; Jeger, M.J.; Gilligan, C.A. Disease control and its selection for damaging plant virus strains in vegetatively propagated staple food crops; a theoretical assessment. Proc. R. Soc. B 2007, 274, 11-18. [CrossRef]

51. Turaki, A.A.; Ahmad, B.; Magaji, U.F.; Abdulrazak, U.K.; Yusuf, B.A.; Hamza, A.B. Optimised cetyltrimethylammonium bromide (CTAB) DNA extraction method of plant leaf with high polysaccharide and polyphenolic compounds for downstream reliable molecular analyses. Afr. J. Biotechnol. 2017, 16, 1354-1365. [CrossRef]

52. Teycheney, P.Y.; Marais, A.; Svanella-Dumas, L.; Dulucq, M.J.; Candresse, T. Molecular characterization of banana virus X (BVX), a novel member of the Flexiviridae family. Arch. Virol. 2005, 150, 1715-1727. [CrossRef] [PubMed]

53. Revers, F.; García, J.A. Molecular biology of potyviruses. In Advances in Virus Research; Elsevier: Amsterdam, The Netherlands, 2005; pp. 101-199. [CrossRef] 
54. Adeniji, M.O.; Shoyinka, S.A.; Ikotun, T.; Asiedu, R.; Hughes, J.A.; Odu, B.O. Yield loss in Guinea yam (Dioscorea rotundata Poir.) due to infection by Yam mosaic virus (YMV) genus Potyvirus. Ife J. Sci. 2012, 14, 237-244.

55. Carrère, I.; Tepfer, M.; Jacquemond, M. Recombinants of cucumber mosaic virus (CMV): Determinants of host range and symptomatology. Arch. Virol. 1999, 144, 365-379. [CrossRef] [PubMed]

56. Eni, A.O.; Kumar, P.L.; Asiedu, R.; Alabi, O.J.; Naidu, R.A.; Hughes, J.; Rey, M.E.C. Characterization of Cucumber mosaic virus isolated from yam (Dioscorea spp.) in West Africa. Afr. J. Biotechnol. 2013, 12, 3472-3480.

57. Toualy, M.N.Y.; Diallo, H.A.; Akinbade, S.A.; Séka, K.; Kumar, P.L. Distribution, incidence and severity of viral diseases of yam (Dioscorea spp.) in Côte d'Ivoire. Afr. J. Biotechnol. 2014, 13, 465-470. [CrossRef]

58. El Far Mervat, M.M.; Ashoub, A. Utility of thermotherapy and meristem tip for freeing sweet potato from viral infection. Aust. J. Basic Appl. Sci. 2009, 3, 153-159.

59. Arkorful, E.; Appiah, A.S.; Dzahini-Obiatey, H. Screening for sweet potato (Ipomoea batatas L.) leaf curl virus (SPLCV) and its elimination using thermotherapy-meristem tip culture technique. J. Agr. Sci. 2015, 10. [CrossRef]

60. Gergerich, R.C.; Welliver, R.A.; Gettys, S.; Osterbauer, N.K.; Kamenidou, S.; Martin, R.R.; Golino, D.A.; Eastwell, K.; Fuchs, M.; Vidalakis, G.; et al. Safeguarding fruit crops in the age of agricultural globalization. Plant Dis. 2015, 99, 176-187. [CrossRef]

61. Bömer, M.; Rathnayake, A.I.; Visendi, P.; Sewe, S.O.; Sicat, J.P.A.; Silva, G.; Kumar, P.L.; Seal, S.E. Tissue culture and next-generation sequencing: A combined approach for detecting yam (Dioscorea spp.) viruses. Physiol. Mol. Plant Pathol. 2019, 105, 54-66. [CrossRef] [PubMed]

62. Filloux, D.; Fernandez, E.; Loire, E.; Claude, L.; Galzi, S.; Candresse, T.; Winter, S.; Jeeva, M.L.; Makeshkumar, T.; Martin, D.P.; et al. Nanopore-based detection and characterization of yam viruses. Sci. Rep. 2018, 8, 17879. [CrossRef] [PubMed]

63. Wang, Q.C.; Valkonen, J.P.T. Elimination of two viruses which interact synergistically from sweetpotato by shoot tip culture and cryotherapy. J. Virol. Methods 2008, 154, 135-145. [CrossRef] [PubMed]

(C) 2020 by the authors. Licensee MDPI, Basel, Switzerland. This article is an open access article distributed under the terms and conditions of the Creative Commons Attribution (CC BY) license (http://creativecommons.org/licenses/by/4.0/). 